\title{
Tadpoles of Rhinella schneideri as reservoirs of trichodinids in continental aquaculture
}

\author{
G. Pala ${ }^{\mathrm{a}}$, G.M.R. Valladão ${ }^{\mathrm{b}}$, L.O. Alves ${ }^{\mathrm{b}}$, F. Pilarski ${ }^{\mathrm{b}}$, E.G. Lux Hoppe ${ }^{\mathrm{a}, *}$ \\ a Departamento de Medicina Veterinária Preventiva, Universidade Estadual Paulista (UNESP), Jaboticabal, São Paulo, Brazil \\ ${ }^{\mathrm{b}}$ Aquaculture Center (CAUNESP), Universidade Estadual Paulista (UNESP), Jaboticabal, São Paulo, Brazil
}

\section{A R T I C L E I N F O}

\section{Keywords:}

Amphibians

Ectoparasites

Electron microscopy

Fish

Host-parasite relationship

\begin{abstract}
A B S T R A C T
Restricted contact between wild amphibians and cultured fish facilitates the transmission of various diseases, including parasitic diseases. The trichodinids are one of the most important ectoparasites in fish farming in continental aquaculture, as they cause significant lesions in the integument and in the gills of the animals, causing mortality outbreaks. Thus the objective of this study is to describe the interaction between trichodinids and wild amphibians found in an earth pond prepared to receive fish from cultivation. Seventy five Rhinella schneideri tadpoles were collected for parasitological assessment. All studied tadpoles were severely parasitized by Trichodina heterodentata, with mean intensity and abundance of $7332 \pm 3689.5$ and range of intensity of 1394-13,240. Despite the high parasitism, no lesions were observed in the animals, mainly due to the large amount of mucus secreted under its integument, forming a protective layer. Wild amphibians are being found inside fish farming tanks, mainly because of the abundant availability of food, providing a calm and ideal environment for breeding. However, tadpoles are able to maintain high rates of parasitism by trichodinids, aiding in the dissemination of parasites to cultured fish. The present work reports for the first time this interrelationship between different species, sharing the same environment and pathogens, with potential damage to the health of commercial farmed hosts.
\end{abstract}

\section{Introduction}

Rhinella schneideri are Bufonidae amphibians widely distributed throughout Brazil, Paraguay, Bolivia, Argentina and Uruguay (Batista et al., 2011; Frost, 2015). The reproduction of these toads undergoes through the rainy season (Giaretta et al., 2008) and the adults are found in streams or lagoons, including ponds used in continental aquaculture (Kloskowski, 2010).

The interaction between wild amphibians and cultured fish may result in parasite sharing, leading to economic losses and/or impact to wildlife health. The expansion of fish farming in new areas favors the emergence of pathogens transmitted by different wild animals (Arechavala-Lopez et al., 2013). As cultured fishes are prone to stress caused by the high stocking density, and the environment favors the accumulation of organic matter, the risk of diseases emergence must be considered (Madsen et al., 2000; Douglas-Helders et al., 2002; Murray, 2009). There are reports of sharing of monogeneans ectoparasites (Sasal et al., 2004), bacteria as Aeromonas salmonicida (Johnsen and Jensen, 1994) and Francisella noatunensis (Johansen et al., 2011), and Infectious Pancreatic Necrosis Virus (Raynard et al., 2007) circulating between populations of wild and cultured fish.

Trichodinids are ciliated protozoa of the Family Trichodinidae, commonly found parasitizing fish worldwide (Soliman et al., 2013). However, these parasites have also been described parasitizing Calanoida copepods (Basson and Van As, 1991; West et al., 2016), the mollusks Biomphalaria scrammi (Pinto et al., 2006), the amphibians Rhinella pombali (Dias et al., 2009), and in the reproductive tract of waterfowl (Carnaccini et al., 2016). The colonization in fish leads to desquamation of the skin and hyperplasia of the lamellar epithelium, with inflammatory infiltration, edema, and necrosis of the gills (AbdelBaki et al., 2011; Yemmen et al., 2011; Valladão et al., 2013; Valladão et al., 2016). In addition to these injuries, the parasitism in fish is associated with reduced growth and immunosuppression, which increases the susceptibility to opportunistic diseases (Lom and Dykova, 1992; Martins et al., 2011).

In general, these parasites present direct lifecycle without host specificity, being able to parasitize both vertebrates and invertebrates (Basson and Van As, 1994; Pinto et al., 2006). Therefore, as several opportunistic aquatic organisms share the same environment with cultivated fish, these pathogens may spread in aquaculture systems.

\footnotetext{
* Corresponding author.

E-mail address: hoppe@fcav.unesp.br (E.G. Lux Hoppe).
} 
Research on the epidemiology of parasites is extremely important to identify possible multiplier hosts and disseminators, which can help create control strategies and biosecurity. Despite being a subject of great importance in veterinary medicine, there are few studies of parasite reservoirs in aquaculture.

A few studies have pointed the risk of wild animals introducing pathogens in the aquaculture environment. So, the aim of this study was to describe the interaction between trichodinids and a wild host in an earth pond prepared to receive fish for cultivation.

\section{Materials and methods}

\subsection{Fish farm and animals}

A permanently full, complete with water earth pond, size $30 \times 10 \mathrm{~m}$, with $1.20 \mathrm{~m}$ in depth, had massive presence of tadpoles of toads. Later, this earth pond would be stocked with Nile tilapia Oreochromis niloticus fingerlings.

About one hundred tadpoles were collected and transported to the Laboratory of Microbiology and Parasitology of Aquatic Organisms of CAUNESP for parasitological assessment. The tadpoles were identified as $R$. schneideri by experts in amphibian taxonomy in Animal Ecology Laboratory, Department of Zoology and Botany-IBILCE, UNESP.

The collection of animals and experimental procedures were approved by the System and Information on Biodiversity with protocol number 51444-1.

\subsection{Limnological variables}

Water samples were collected and stored in 11 bottles for water quality assessment. The variables Dissolved Oxygen (mg/l) and Temperature $\left({ }^{\circ} \mathrm{C}\right.$ ) were determined with a digital oximeter (YSI 55 model) and the $\mathrm{pH}$ with a pHmeter (YSI pH 100 model). At the Caunesp Water Analyses Laboratory, the variables Total Ammonia ( $\mu \mathrm{g} / \mathrm{l})$ (Koroleff, 1976), Nitrate ( $\mu \mathrm{g} / \mathrm{l})$ e Nitrite $(\mu \mathrm{g} / \mathrm{l})$ (Golterman, 1978), and Total Phosphorus ( $\mu \mathrm{g} / \mathrm{l})$ (Mackereth et al., 1978) were determined. The reference values were obtained from the CONAMA Resolution no. 357 (Brasil, 2005).

\subsection{Parasitological diagnostic and taxonomic evaluation}

In laboratory conditions, preliminary scrapings of integument and gill tissue indicated an intense infestation by trichodinids. For determination of the parasite load, each tadpole $(n=60)$ was placed in a test tube with $2 \mathrm{ml}$ of formalin 1:4000 during $2 \mathrm{~h}$ for the detachment of the parasites. Subsequently, $1 \mathrm{ml}$ of the content was added to a Sedgwick-Rafter chamber for parasite counting under a Nikon E200 ${ }^{\circledR}$ optical microscope. The obtained number of trichodinids was multiplied by 2 in order to estimate the parasite load of each tadpole. The prevalence, mean abundance, and mean intensity were calculated after Bush et al. (1997).

For trichodinid identification, the remaining $1 \mathrm{ml}$ was deposited on glass slides, air-dried, and impregnated with silver nitrate $2 \%$, following the method of Klein (1958). Photomicrographs were obtained in Nikon microscope $\mathrm{E}^{200^{\circledast}}$ equipped with Motic 5.0 images capture system. Measurements of taxonomic characters were performed according to the recommendations of Lom (1958) and Basson and Van As (1989), using the software Image Pro Plus ${ }^{\circledR}$ 7.0. The taxonomic data are expressed as mean \pm standard deviation (min-max). Schematic drawings of the denticles were produced as proposed by Basson and Van As (1989), using the software CorelDRAW ${ }^{\circledR}$ X8.

\subsection{Host-parasite interactions}

For histopathologic analyses, the gills of ten tadpoles, which were fixed in $10 \%$ buffered formalin, were embedded in paraffin, sectioned
Table 1

Obtained limnological values and parameters of reference.

\begin{tabular}{lll}
\hline Limnological value & Observed in this study & Reference values ${ }^{\mathrm{a}}$ \\
\hline Temperature $\left({ }^{\circ} \mathrm{C}\right)$ & 20.9 & $20.0-28.0$ \\
Dissolved oxygen $(\mathrm{mg} / \mathrm{l})$ & 5.7 & $>5.0$ \\
$\mathrm{pH}$ & 7.1 & $6.5-8.0$ \\
Nitrite $(\mathrm{mg} / \mathrm{l})$ & 0.05 & $\leq 1.0$ \\
Nitrate $(\mathrm{mg} / \mathrm{l})$ & 0.65 & $\leq 10.0$ \\
Total ammonia $(\mathrm{mg} / \mathrm{l})$ & 0.12 & $\leq 2.0$ \\
Total phosphorus $(\mathrm{mg} / \mathrm{l})$ & 0.08 & $\leq 0.03$
\end{tabular}

a Brasil, 2005.

in microtome, and stained with hematoxylin-eosin. Photomicrographs were obtained using the Nikon E200 ${ }^{\circledR}$ microscope equipped with image capture system Moticam 2300 ${ }^{\circledR}$.

For electron microscopy analysis, five tadpoles fixed in buffered glutaraldehyde $2.5 \%$ were post-fixed in osmium tetroxide $1 \%$. Subsequently, the samples were dehydrated in a series of alcohols and critical point dried. The resultant material was mounted in aluminum stubs and coated with gold. The photomicrographs were obtained in scanning electron microscope JEOL JSM-5410. The whole body surface was analyzed, focusing on the tail, skin, eyes, nostrils and gill cavity.

\section{Results}

\subsection{Limnological variables}

The determined limnological values and their respective reference parameters are listed on Table 1. All the values, except total phosphorus, were adequate for tropical fish farming.

\subsection{Parasitological diagnostic}

All tadpoles analyzed were heavily parasitized (100\% prevalence) by trichodinids with mean abundance and intensity of infestation of $7332 \pm 3689.5$ (1394-13,240). Parasites were observed on the body surface, gills, nostrils and mouth, but macroscopic lesions were not observed.

\subsection{Trichodinid description}

The morphometric data of trichodinids found in $R$. schneideri tadpoles are shown in Table 2. The denticle blade presented a typical sickle shape and, in general, filled all the space between the axis y and $\mathrm{y}+1$. The shape of the posterior portion of the blade varied between rounded or sharp. A prominent apophysis was observed at the anterior margin of

Table 2

Morphometric data (in $\mu \mathrm{m}$ ) of the population of Trichodina heterodentata infesting tadpoles of Rhinella schneideri of the present study.

\begin{tabular}{ll}
\hline Parasite species & Trichodina heterodentata \\
\hline Infection site & Skin and gill \\
Body $^{\mathrm{D}}$ & $54.52 \pm 6.2(38.75-59.34 ; 60)$ \\
Adhesive disc $^{\mathrm{D}}$ & $47.96 \pm 5.41(39.54-54.14 ; 60)$ \\
Border membrane $^{\mathrm{W}}$ & $4.26 \pm 0.71(3.17-7.40 ; 60)$ \\
Denticulate ring $^{\mathrm{D}}$ & $30.28 \pm 3.16(24.86-32.34 ; 60)$ \\
Number of denticles & $22(19-23 ; 60)$ \\
Pines per Denticle $_{\text {Denticle }^{\mathrm{L}}}$ & $8(7-11 ; 60)$ \\
Blade $^{\mathrm{L}}$ & $6.48 \pm 1.12(5.85-8.64 ; 60)$ \\
Central portion $^{\mathrm{W}}$ & $4.42 \pm 0.74(4.04-6.23 ; 60)$ \\
Ray $^{\mathrm{L}}$ & $2.14 \pm 0.33(2.01-3.11 ; 60)$ \\
Span $^{\mathrm{L}}$ & $6.19 \pm 0.94(4.28-8.55 ; 60)$ \\
\hline
\end{tabular}

Measurement data were described as the mean \pm standard deviation (minimum maximum; number of structures measured), ${ }^{\mathrm{L}}=$ length, $^{\mathrm{D}}=$ diameter and $^{\mathrm{w}}=$ width. 

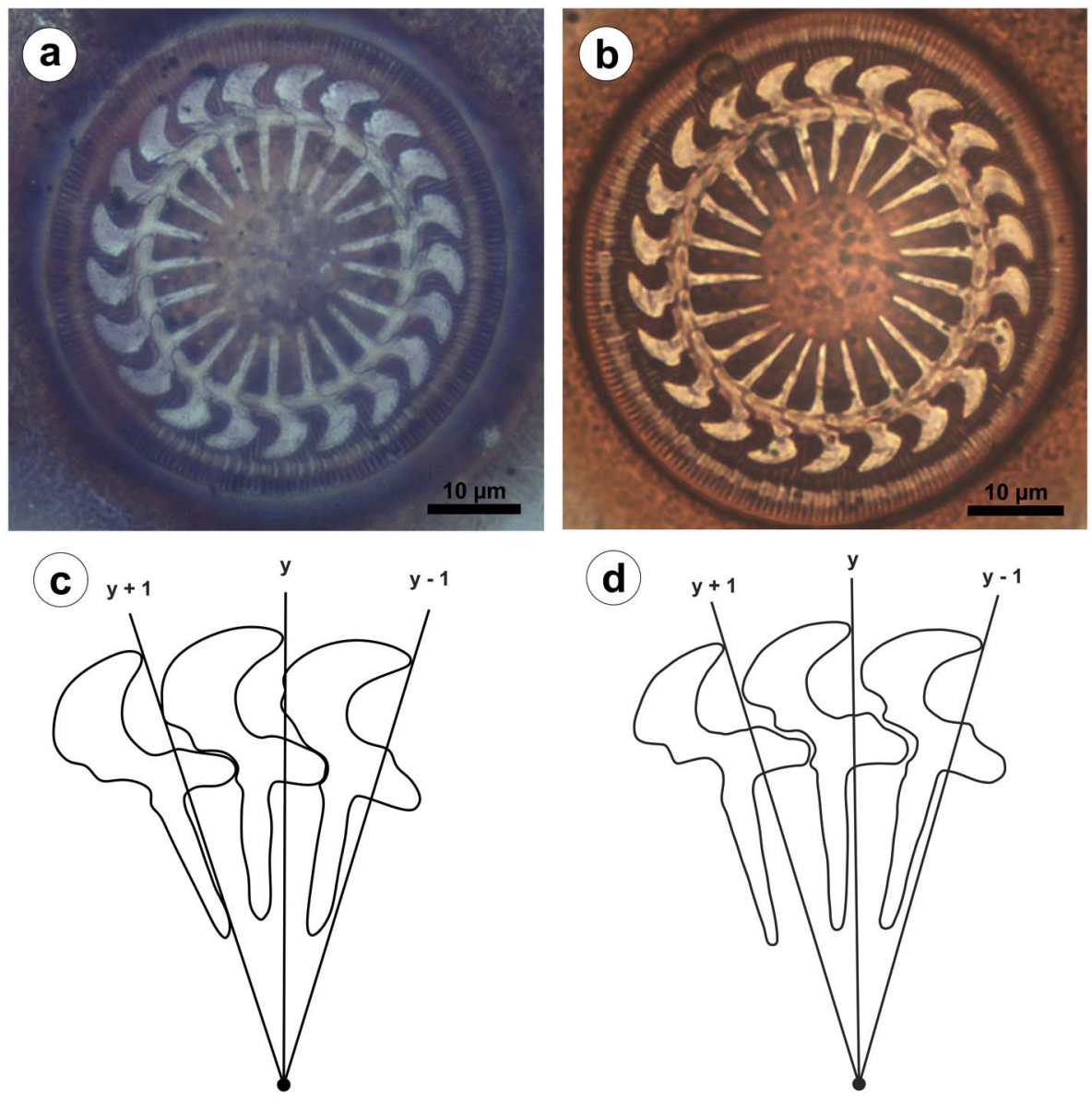

Fig. 1. A, B: Trichodina heterodentata stained with silver nitrate C, D: Two schematic drawings demonstrating the variation found in this population. the blade. The central part filled half of the y-axis, and rare apophyses were observed in some specimens. The long ray showed an apophysis, presented variable thickness with rounded or pointed tips. The position of the ray in relation to the y axis was heterogeneous. Based on measurements and morphological description, the specimens from this study were identified as Trichodina heterodentata (Fig. 1).

\subsection{Host-parasite interactions}

The histopathology revealed that the gills did not show characteristic lesions indicating parasitism by trichodinids, such as hyperplasia and lamellar hypertrophy, areas of necrosis, hemorrhage, inflammatory infiltrate, among others. Despite the presence of trichodinids in the branchial chamber, the structures were preserved (Fig. 2).
In scanning electron microscopy, even though there were several specimens of trichodinids were observed infesting the mouth, tail, nostrils, around the eyes, head, and integument there were not the lesions compatible with fixation of the parasite, normally as found in fish parasitized by this parasite (Fig. 3).

\section{Discussion}

There are few studies about parasites in tadpoles and, to the best of our knowledge, this is the first record of trichodinid parasitizing $R$. schneideri. There is one report of Trichodina steini (Kattar, 1975) parasitizing tadpoles of the phylogenetically close species Rhinella icterica and two additional reports of T. heterodentata (Dias et al., 2009; Fernandes et al., 2011) parasitizing Rhinella pombali tadpoles. Even

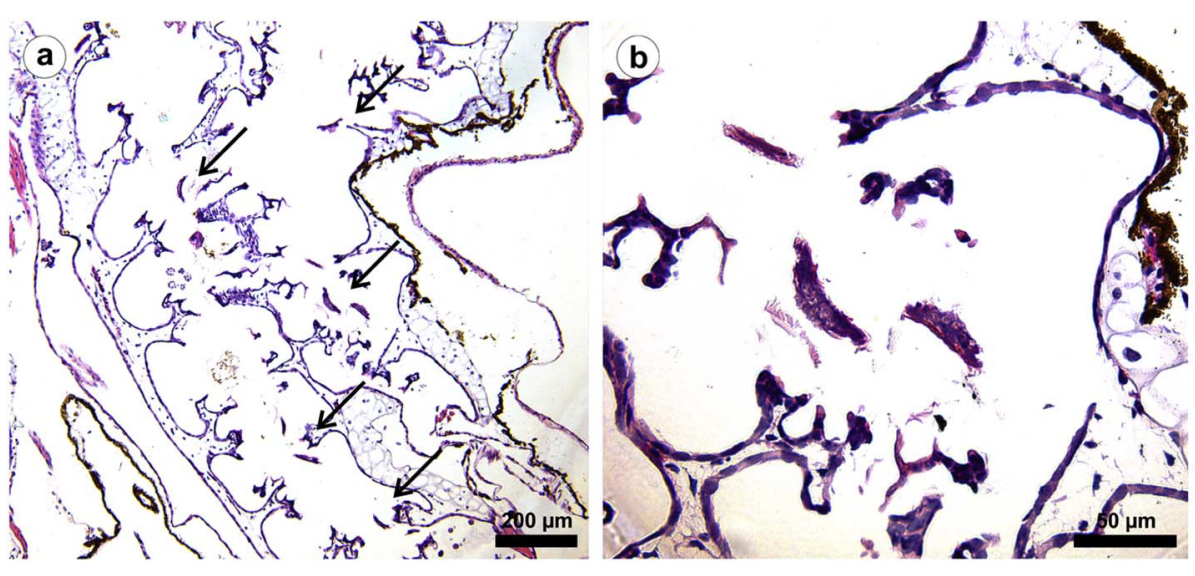

Fig. 2. A: Intense parasitism by Trichodina heterodentata (arrows) in gill chamber of Rhinella schneideri tadpoles. B: In particular, the trichodinids infesting the gill tissue. Hyperplasia, hypertrophia, necrosis, hemorrhage, and other pathological alterations were not observed. 

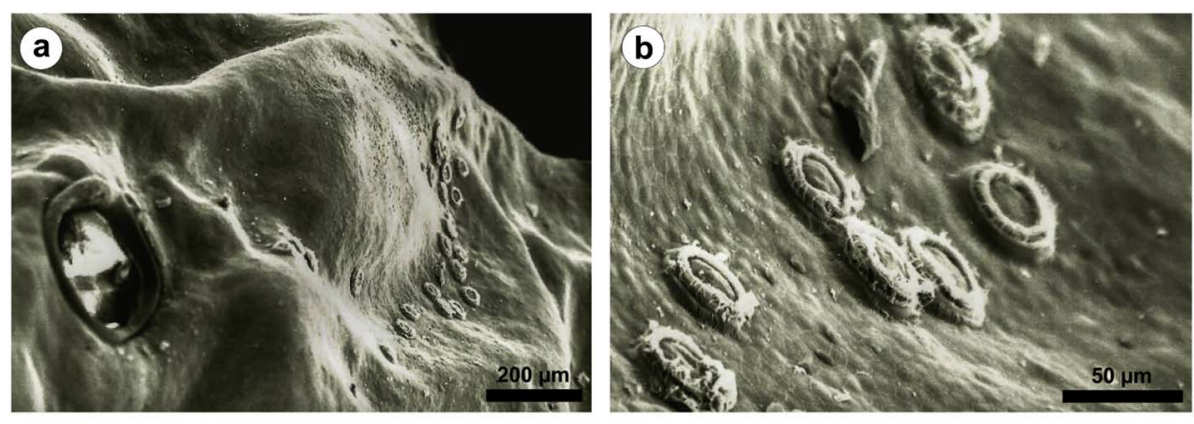

Fig. 3. A, B: Scanning electron microscopy of T. heterodentata parasitizing the head of Rhinella schneideri tadpole. The integument is integer, despite the presence of trichodinids in the surface. C: In detail, two trichodinids on the outer surface of the body. D: Opercular chamber and gills of a tadpole intensely parasitized by trichodinids.
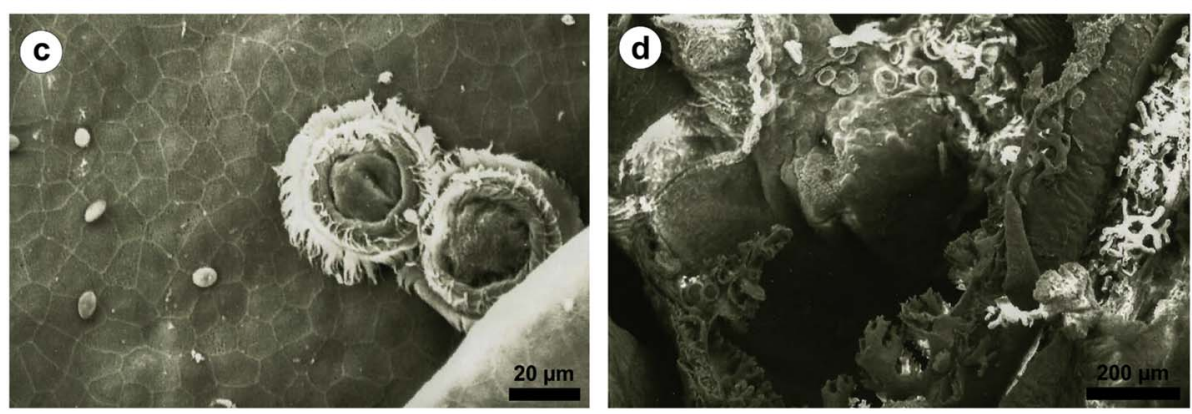

though, none of these records was associated with farmed animals and the description of tadpole as reservoirs of diseases in aquaculture is lacking. Through morphological and morphometric analysis of this study the specimen was identified as T. heterodentata. This trichodinid parasite is commonly found in a wide range of hosts because its low host specificity (Dias et al., 2009), as Ictalurus punctatus (Martins et al., 2010), Piaractus mesopotamicus (Pádua et al., 2012), Arapaima gigas (Miranda et al., 2012), Prochilodus lineatus (Valladão et al., 2014), and O. niloticus (Valladão et al., 2016). The parasitic intensity values of the present study $(7332 \pm 3689.5)$ were higher than those found in $R$. pombali tadpoles (695.14 \pm 335.12 ) (Fernandes et al., 2011), and in tilapia fingerlings from two different fish farms (197.67 \pm 202.24 and $31.8 \pm 19.07$ ) (Valladão et al., 2016).

Trichodina heterodentata shows a wide range of polymorphisms, including morphometric and morphological variations, in different populations, as observed by Duncan (1977). Additionaly, in Brazil, there are known variations in size of the denticles and rays of a population obtained from $R$. pombali tadpoles (Dias et al., 2009); morphometric differences in the adhesive disc denticulated ring, central part, and span in populations from I. puntactus (Martins et al., 2010); and morphometric differences in the rays of some specimens of a population affecting P. mesopotamicus (Pádua et al., 2012). The population analyzed in this study presented variations on the rays shape, with some specimens even showing a terminal apophysis. On the other hand, Van As and Basson (1987) suggest that these parasites have high host specificity and possible morphological variations are due to confuse taxonomy, even though they ponder that these parasites are opportunistic, especially in fish farming. Considering this, further molecular studies should be conducted in order to evaluate the specific identification and clarify this point.

In fish, trichodinids are known to cause hypertrophy and hyperplasia of the lamellar epithelium, sub-epithelial edema, extensive areas of necrosis and intense mononuclear inflammatory infiltrate in gill tissue (Valladão et al., 2014), erosion and desquamation of the skin (Valladão et al., 2016). The reason by which trichodinids did not cause relevant injuries tadpoles, even at heavy infestation, may be due to the fact that these tadpoles were living in natural conditions, while the fish are cultivated in overpopulation, prone to stressful conditions that culminate in immunosuppression (Terova et al., 2005; Tort, 2011). In addition, the water of the studied earth pond had the Total Phosphorus higher than acceptable for lentic waters used in aquaculture (Brasil,
2005), indicating eutrophication. Poor water quality is one of the predisposing factors to trichodinid proliferation (Madsen et al., 2000; Ogut and Palm, 2005), explaining the high infestation descriptors observed.

The relative disease resistance of the tadpoles may be linked to other factors such as different protection structures of their skin including the mucus components, the immune system of the species, or even as a result of an adaptation between the host and the parasite. The tadpoles also present an expressive mucous secretion on the body surface (Regueira et al., 2016). The presence of this mucus and resultant viscosity may reduce the contact of the parasites with the tegument, reducing damage even in heavy infestations.

A study addressing exchange of parasites among endemic and exotic species shows that the most dominant infections of exotic species is the result of spillover of generalist parasites of native species (Kelly et al., 2009). It should be highlighted that the presence of frogs in farm ponds can increase environmental contamination by parasites, with possible negative impact on the farmed animals. The prevention or control of wild animals into farming systems is highly recommended to prevent important trichodinid infections, especially in tanks that will receive fish larvae.

Thus, tadpoles found in fish culture tanks probably are natural reservoirs of trichodinids, transmitting them to farmed fish. On this, Maciel et al. (2017) recently highlighted the great need for more precise information regarding trichodiniasis transmission and the present work reports for the first time this interrelationship between different hosts, sharing the same environment and pathogens, with potential damage to the health of commercial farmed hosts.

\section{Conflict of interest}

The authors declare no conflicts of interest.

\section{References}

Abdel-Baki, A.S., Sakran, T., Fayed, H., Zayed, E., 2011. Trichodina fahaka (Ciliophora: Peritrichia) in Tetradon fahaka from Nile River, Egypt: seasonality and histopathology. Sci. Res. Essays 6, 1583-1587.

Arechavala-Lopez, P., Sanchez-Jerez, P., Bayle-Sempere, J.T., Uglem, I., Mladineo, I., 2013. Reared fish, farmed escapees and wild fish stocks - a triangle of pathogen transmission of concern to Mediterranean aquaculture management. Aquac. Environ. Interact. 153, 153-161.

Basson, L., Van As, J.G., 1989. Differential diagnosis of the genera in the family Trichodinidae (Ciliophora: Peritrichida) with the description of a new genus 
ectoparasitic on freshwater fish from southern Africa. Syst. Parasitol. 13, 153-160.

Basson, L., Van As, J.G., 1991. Trichodinids (Ciliophora: Peritrichia) from a calanoid copepod and catfish from South Africa with notes on host specificity. Syst. Parasitol. 18, 147-158.

Basson, L., Van As, J.G., 1994. Trichodinid ectoparasites (Ciliophora: Peritrichida) of wild and cultured freshwater fishes in Taiwan, with notes on their origin. Syst. Parasitol. 28, 197-222.

Batista, R.C., Carvalho, C.B., Freitas, E.B., Cunha, S., Franco, C.D.C.B., Coelho, W.A., Faria, R.G., 2011. Diet of Rhinella schneideri (Werner, 1894) (Anura: Bufonidae) in the Cerrado, central Brazil. Herpetol. Notes 4, 17-21.

Brasil, 2005. Conselho Nacional do Meio Ambiente. Resolução CONAMA no. 357, de 17 de março de 2005. Classificação de águas, doces, salobras e salinas do Território Nacional. Publicado no D.O.U.

Bush, A.O., Lafferty, K.D., Lotz, J.M., Shostak, A.W., 1997. Parasitology meets ecology on its own terms: Margolis et al. revisited. J. Parasitol. 575-583.

Carnaccini, S., Lowenstine, L.J., Sentíes-Cué, C.G., Nyaoke, A., Bland, M., Bickford, A.A., Stoute, S.T., 2016. Trichodinosis associated with pathology of the reproductive tract in waterfowl. Avian Pathol. 45, 418-425.

Dias, R.J.P., Fernandes, N.M., Sartini, B., Silva-Neto, I.D., D'Agosto, M., 2009. Occurrence of Trichodina heterodentata (Ciliophora: Trichodinidae) infesting tadpoles of Rhinella pombali (Anura: Bufonidae) in the Neotropical area. Parasitol. Int. 58, 471-474.

Douglas-Helders, G.M., Dawson, D.R., Carson, J., Nowak, B.F., 2002. Wild fish are not a significant reservoir for Neoparamoeba pemaquidensis (page, 1987). J. Fish Dis. 25, 569-574.

Duncan, B.L., 1977. Urceolariid ciliates, including three new species, from cultured Philippine fishes. Trans. Am. Microsc. Soc. 96, 76-81.

Fernandes, N.M., Sartini, B., Dias, R.J., D'Agosto, M., 2011. Quantitative study of Trichodina heterodentata (Ciliophora: Mobilia) infrapopulations infesting tadpoles of a Brazilian endemic toad Rhinella pombali (Anura: Bufonidae). Zoologia 28, 777-783.

Frost, D.R., 2015. Amphibian Species of the World: An Online Reference. Version 6.0. Electronic Database. http://research.amnh.org/herpetology/amphibia/index. htmlAmerican Museum of Natural History, New York, USA (accessed June 2017).

Giaretta, A.A., Menin, M., Facure, K.G., Kokubum, M.N.D.C., Oliveira Filho, J.C.D., 2008. Species richness, relative abundance, and habitat of reproduction of terrestrial frogs in the Triângulo Mineiro region, Cerrado biome, southeastern Brazil. Iheringia. Sér. Zool. 98, 181-188.

Golterman, H.L., 1978. Methods for Chemical Analysis of Freshwater. Blackwell Scientific Publications, Oxford and Edinburgh (172p).

Johansen, L.H., Jensen, I., Mikkelsen, H., Bjørn, P.A., Jansen, P.A., Bergh, Ø., 2011. Disease interaction and pathogens exchange between wild and farmed fish populations with special reference to Norway. Aquaculture 315, 167-186.

Johnsen, B.O., Jensen, A.J., 1994. The spread of furunculosis in salmonids in Norwegian rivers. J. Fish Biol. 45, 47-55.

Kattar, M.R., 1975. Sobre Trichodina steini Claparède \& Lachmann (Protozoa: Urceolariidae) encontrada em girino de Bufo ictericus do Brasil. Braz. J. Biol. 35, 253-258.

Kelly, D.W., Paterson, R.A., Townsend, C.R., Poulin, R., Tompkins, D.M., 2009. Parasite spillback: a neglected concept in invasion ecology? Ecology 90, 2047-2056.

Klein, B.M., 1958. The "dry" silver method and its proper use. J. Eukaryot. Microbiol. 5, 99-103.

Kloskowski, J., 2010. Fish farms as amphibian habitats: factors affecting amphibian species richness and community structure at carp ponds in Poland. Environ. Conserv. 37, 187-194.

Koroleff, F., 1976. Determination of nutrients. In: Grasshoff, K. (Ed.), Methods of Seawater Analysis. Verlag Chemie Weinheim, New York, pp. 117-181.

Lom, J., 1958. A contribution to the systematics and morphology of endoparasitic trichodinids from amphibians, with a proposal of uniform specific characteristics. J. Eukaryot. Microbiol. 5, 251-263.

Lom, J., Dykova, I., 1992. Protozoan Parasites of Fish. Developments in Aquaculture and Fisheries Science. 26 Elsevier, Amsterdam.
Maciel, P.O., Garcia, F., Chagas, E.C., Fujimoto, R.Y., Tavares-Dias, M., 2017. Trichodinidae in commercial fish in South America. Rev. Fish Biol. Fish. 1-24.

Mackereth, F.H., Heron, J., Talling, J.F., 1978. Water Analysis: Some Revised Methods for Limnologists. Freshwater Biological Association, Ambleside, pp. 36 (121p).

Madsen, H.C., Buchmann, K., Mellergaard, S., 2000. Trichodina sp. (Ciliophora: Peritrichida) in eel Anguilla anguilla in recirculation systems in Denmark: host-parasite relations. Dis. Aquat. Org. 42, 149-152.

Martins, M.L., Marchiori, N., Nunes, G., Rodrigues, M.P., 2010. First record of Trichodina heterodentata (Ciliophora: Trichodinidae) from channel catfish, Ictalurus punctatus cultivated in Brazil. Braz. J. Biol. 70, 637-644.

Martins, M.L., Shoemaker, C.A., Xu, D., Klesius, P.H., 2011. Effect of parasitism on vaccine efficacy against Streptococcus iniae in Nile tilapia. Aquaculture 314, 18-23.

Miranda, L.H., Marchiori, N., Rebaza Alfaro, C., Martins, M.L., 2012. First record of Trichodina heterodentata (Ciliophora: Trichodinidae) from Arapaima gigas cultivated in Peru. Acta Amazon. 42, 433-438.

Murray, A.G., 2009. Using simple models to review the application and implications of different approaches used to simulate transmission of pathogens among aquatic animals. Prev. Vet. Med. 88, 167-177.

Ogut, H., Palm, H.W., 2005. Seasonal dynamics of Trichodina spp. on whiting (Merlangius merlangus) in relation to organic pollution on the eastern Black Sea coast of Turkey. Parasitol. Res. 96, 149-153.

Pádua, S.B., Martins, M.L., Carraschi, S.P., Cruz, C., Ishikawa, M.M., 2012. Trichodina heterodentata (Ciliophora: Trichodinidae): a new parasite for Piaractus mesopotamicus (Pisces: Characidae). Zootaxa 3422, 62-68.

Pinto, H.A., Wieloch, A.H., Melo, A.L., 2006. Uma nova espécie de Trichodina Ehrenberg, 1838 (Ciliophora: Trichodinidae) em Biomphalaria schrammi (Crosse, 1864) (Mollusca: Planorbidae). Lundiana 7, 121-124.

Raynard, R., Wahli, T., Vatsos, I., Mortensen, S., 2007. Review of disease interactions and pathogen exchange between farmed and wild finfish and shellfish in Europe. In: DIPNET Project Report.

Regueira, E., Dávila, C., Hermida, G.N., 2016. Morphological changes in skin glands during development in Rhinella arenarum (Anura: Bufonidae). Anat. Rec. 299, $141-156$.

Sasal, P., Desdevises, Y., Durieux, E., Lenfant, P., Romans, P., 2004. Parasites in marine protected areas: success and specificity of monogeneans. J. Fish Biol. 64, 370-379.

Soliman, F.M., Abd El-Galil, M.A.A., Adly, M.A., Fatma El Zahraa, A.A., 2013. Studies on trichodinosis of some cultured freshwater fishes at Sohag governorate. Life Sci. J. 10, 1400-1409.

Terova, G., Gornati, R., Rimoldi, S., Bernardini, G., Saroglia, M., 2005. Quantification of a glucocorticoid receptor in sea bass (Dicentrarchus labrax, L.) reared at high stocking density. Gene 357, 144-151.

Tort, L., 2011. Stress and immune modulation in fish. Dev. Comp. Immunol. 35, 1366-1375.

Valladão, G.M.R., Pádua, S.B., Gallani, S.U., Menezes-Filho, R.N., Dias-Neto, J., Martins, M.L., Pilarski, F., 2013. Paratrichodina africana (Ciliophora): a pathogenic gill parasite in farmed Nile tilapia. Vet. Parasitol. 197, 705-710.

Valladão, G.M.R., Gallani, S.U., Pádua, S.B., Martins, M.L., Pilarski, F., 2014. Trichodina heterodentata (Ciliophora) infestation on Prochilodus lineatus larvae: a host-parasite relationship study. Parasitology 141, 662-669.

Valladão, G.M.R., Alves, L.O., Pilarski, F., 2016. Trichodiniasis in Nile tilapia hatcheries: diagnosis, parasite: host-stage relationship and treatment. Aquaculture 451 , 444-450.

Van As, J.G., Basson, L., 1987. Host specificity trichodinid ectoparasites of freshwater fish. Parasitol. Today 3, 88-90.

West, D., Basson, L., Van As, J., 2016. Trichodina diaptomi (Ciliophora: Peritrichia) from two calanoid copepods from Botswana and South Africa, with notes on its life history. Acta Protozool. 55, 161-171.

Yemmen, C., Ktari, M.H., Bahri, S., 2011. Seasonality and histopathology of Trichodina puytoraci Lom, 1962, a parasite of flathead mullet (Mugil cephalus) from Tunisia. Acta Adriat. 52, 15-20. 